\title{
ANALISIS GEOKIMIA DAN METODE GEOLISTRIK RESISTIVITAS 2D UNTUK MENGETAHUI ALIRAN LINDI DI TPA BABAKAN CIPARAY
}

\author{
Mia Uswatun Hasanah ${ }^{1}$, Nanang Dwi Ardhi $^{2}$, Mimin Iriyanti $^{2}, \&$ Selly Ferani ${ }^{2}$ \\ ${ }^{1}$ Laboratorium Geofisika, Departemen Geofisika, Universitas Padjadjaran \\ ${ }^{2}$ Program Studi Fisika, Universitas Pendidikan Indonesia \\ *Alamat korespondensi: hasanah@geophys.unpad.ac.id
}

\begin{abstract}
Abstrak: Metode geolistrik dapat diaplikasikan dalam berbagai bidang keilmuan termasuk lingkungan. Pada penelitian ini memanfaatkan perbedaan resistivitas untuk mengetahui aliran lindi di Tempat Pembuangan Akhir (TPA) Babakan Ciparay, dengan melihat hasil citra bawah permukaan dan diperkuat dengan analisis geokimia. Konfigurasi yang digunakan adalah Wenner dengan spasi elektroda minimum adalah 5 meter. Hasil penelitian menunjukan bahwa lindi mengalir menuju ke arah utara dan ke dataran yang lebih rendah. Hal tersebut dapat dilihat dari nilai resistivitas yang berada pada kisaran $0.019-6.51 \Omega \mathrm{m}$ dan $0.9-7,5 \Omega \mathrm{m}$. Rentang resitivitas tersebut berada di bawah nilai resistivitas untuk air bersih (fresh water) yakni antara $10-100 \Omega \mathrm{m}$ (Loke, 1997). Hasil tersebut diperkuat dengan hasil uji kualitas air yang dilakukan terhadap parameter kadar nitrit, nitrat, Amoniak total, Fe dan COD. Beberapa parameter kimia tersebut menunjukan bahwa untuk air yang berasal dari kawasan permukiman masih dikategosikan air bersih dan layak, akan tetapi beberapa aliran yang menuju ke wilayah tersebut sudah mengalami pencemaran lindi.
\end{abstract}

Kata kunci: Geolistrik, Geokimia, Lindi, TPA, Ciparay.

Abstract: Resistivity method is one of applied geopysics on enviromental issues. In this study resistivity variation and anomaly used to determine the leachate flow in the Babakan Ciparay landfill. The imaging of subsurface resistivity distribution and geochemical analysis lead to describe the area contaminated. Wenner configuration was used with the minimum electrode spacing in 5 meters. The results showed that the leachate flows to the northern part of landfill and to the lower terain. It can be seen from the value of resistivity in the range of $0.019-6.51 \Omega m$ and $0.9-7.5 \Omega \mathrm{m}$. The resitivity range is below the resistivity of water (fresh water) which is between 10-100 $\Omega m$ (Loke, 1997). These results also in agreemeent with the results of water quality tests. Water quality test was conducted for some parameters including nitrite, nitrate, total ammonia, Fe and COD. Some chemical parameters show that water in housing area still categorized as a clean water and decent, but some flows headed to the region is already contaminated leachate.

Keywords: Geophysic, Resistivity Method, Landfill, Leachete, Ciparay.

\section{PENDAHULUAN}

Kerusakan lingkungan semakin banyak terjadi diakibatkan oleh adanya kemajuan teknologi yang tidak diiringi dengan kemampuan dalam mengolah limbah. Semakin tingginya aktivitas manusia maka akan meningkatkan jumlah limbah yang dihasilkan. Limbah yang dihasilkan akibat aktivitas manusia, baik dalam bentuk cair, padat ataupun gas, merupakan ancaman yang bila tidak di antisipasi secara dini dan tepat akan merupakan bencana bagi kehidupan di bumi (Notodarmojo, 2005).

Limbah yang tak terkendali akibat pengelolaan yang sederhana dan tanpa didukung kondisi geologi dapat mengakibatkan peresapan limbah ke dalam air tanah. Air merupakan sumber daya alam yang sangat penting bagi manusia. Kualitas air menjadi sangat penting karena sebagian besar pengguna air menggunakan air tersebut secara langsung. Kadar zat atau ion dalam air tergantung pada jenis dan tingkat bahaya kontaminan serta besarnya bidang kontak anatara ontaminan dan air (Notodarmojo, 2005).
Limbah dari timbunan sampah dapat menimbulkan cairan yang membahayakan yang disebut lindi. Lindi merupakan limbah cair yang berasal dari sampah basah atau sampah organik yang terkena air hujan. Jika lindi tersebut tidak diolah dengan baik, maka dapat menyebar ke dalam tanah dan masuk ke lapisan air tanah yang dapat menyebabkan pencemaran air tanah. Lindi tersebut mengandung zat-zat berbahaya bagi tubuh seperti adanya kandungan $\mathrm{Hg}, \mathrm{H}_{2} \mathrm{~S}$ ataupun zat kimia lainya, tergantung jenis sampah yang dibuang di TPA tersebut. Lindi atau limbah cair sampah mempunyai konduktivitas yang berbeda dengan air tanah, lindi mempunyai konduktivitas yang lebih tinggi dibandingkan dengan air tanah (Darsono, 2008). Maka terdapat perbedaan konduktivitas yang dapat diamati dengan metode geolistrik resistivitas (Loke, 2000). Nilai resistivitas air bersih (fresh water) adalah antara $10-100 \Omega \mathrm{m}$. Sedangkan nilai resistivitas lindi memiliki nilai yang lebih kecil. Pada penelitan yang telah dilakukan di TPA dengan metode sounding diperoleh hasil pada bekas 


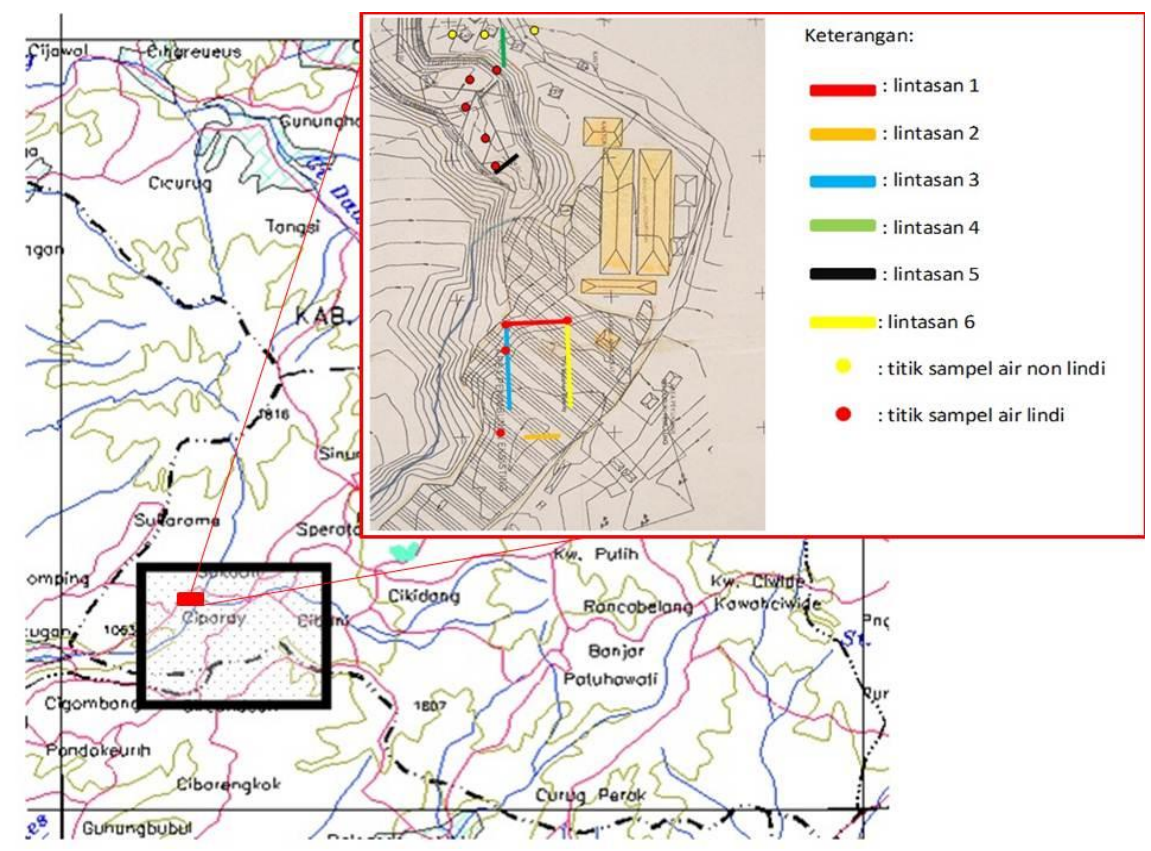

Gambar 1. Lokasi Penelitian dimodifikasi dari peta dalam (Marganingrum, 2006)

tumpukan sampah $<15 \Omega \mathrm{m}$ sedang pada zona utamanya $<8 \Omega \mathrm{m}$ dan $100-200 \Omega \mathrm{m}$ untuk fresh water (Marganingrum, 2006). Selain itu berdasarkan penelitian yang dilakukan oleh Asri dkk pada tahun 2001 di TPA Ciparay diperoleh hasil nilai tahanan jenis yang merepresentasikan pencemaran disekitar TPA kecamatan Ciparay yaitu pada range $8 \Omega \mathrm{m}-12$ $\Omega \mathrm{m}$. Keberadaan kontras resistivitas memberi informasi keadaan air tanah di suatu tempat.

Dalam penelitian ini kami menggunakan metode eksplorasi geofisika yaitu metode geolistrik tahanan jenis untuk mengetahui persebaran dari lindi Metode geolistrik tahanan jenis dilakukan untuk melihat lapisan-lapisan dibawah permukaan dengan kedalaman dangkal, sekitar 3 - 100 meter (Burkhard Sanner:2). Serta diperlukan uji kualitas air dengan menghitung kandungan kimia yang berbahaya diperuntukan untuk mengetahui kualitas air tanah yang tercemar.

\section{METODE}

\section{Lokasi Penelitian}

Lokasi penelitian adalah TPA Babakan ciparay yang terletak di kabupaten Bandung terlihat pada Gambar 1, lokasi berada pada koordinat 92159540 $\mathrm{mT}$ - $9216890 \mathrm{mT}$ dan $796220 \mathrm{mU}-796910 \mathrm{mU}$ dengan ketinggian \pm 690 meter hingga \pm 700 meter di atas permukaan laut.

\section{Pengambilan Data Penelitian}

Pada penelitian ini data yang digunakan adalah data geofisika dan geokimia. Dengan menggabungkan kedua data tersebut dapat dihasilkan gambaran penyebaran lindi di TPA ciparay.Data geokimia menjadi data yang mendukung kondisi tercemarnya air di wilayah penduduk, seperti yang diperlihatkan pada Gambar 2.

\section{Geofisika Metode resistivitas}

Pengambilan data dilakukan pada enam lintasan pengamatan yang berada pada lokasi TPA hingga ke wilayah pemukinan penduduk. Seperti pada gambar 3(e) lintasan dibuat di sekitar tumpukan sampah dan wilayah yang menuju ke pemukiman penduduk. Lintasan terdiri dari enam lintasan, empat lintasan tepat di atas sampah dan sisanya berada di daerah mendekati wilayah pemukiman penduduk.

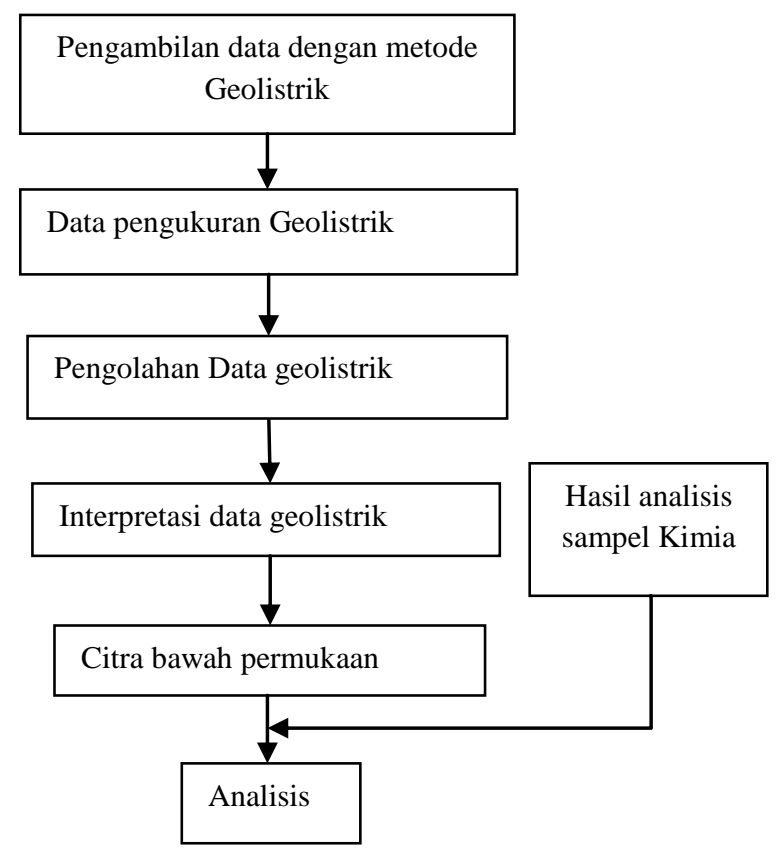

Gambar 2. Bagan Alur Metode Penelitian 
Pemilihan daerah tepat di atas sampah untuk memperoleh gambaran resistivitas pada wilayah yang memang mengandung lindi untuk mempermudah interpretasi pada hasil pencitraan di wilayah yang mendekati kawasan pemukiman. Lintasan tesebut dipilih untuk mengetahui citra yang dihasilkan dan arah aliran dari pencemaran. Pengambilan data dilakukan dengan metode geolistrik resistivitas dengan konfigurasi Wenner.

Pada penelitian ini dipilih metode wenner karena hasil berupa penampang 2D yang mempertmudah dalam melakukan interpretasi. Pada penelitian ini spasi elektrodanya $5 \mathrm{~m}$ agar data yang diperoleh cukup detail dengan efektifitas waktu pengambilan data dengan bentangan 45-110 meter.

\section{Geokimia}

Selain metode geofisika, penelitian ini menggunakan data geokimia untuk memperoleh hasil interpretasi yang ilmiah. .Berdasarkan parameter geokimia terdapat beberapa hal yang dapat diukur untuk menjadi standarisasi air tercemar.Pengujian dilakukan pada beberapa mineral yang terkandung, diantaranya pengujian $\mathrm{pH}$, DHL, Temperatur, TDS, salinitas, $\mathrm{Fe}, \mathrm{COD}, \mathrm{NO}_{2}^{-}, \mathrm{NO}_{3}{ }^{-}$dan Amoniak total.

Data tersebut digunakan untuk mendukung analisa hasil pengolahan data geolistrik dengan membandingkan variasi nilai resistivitas.

Terdapat 2 jenis sampel air yang diamati, yakni air yang digunakan di wilayah penduduk dan air yang tersebar di wilayah TPA, untuk sampel pada air sumur warga masih dapat dikategorikan air bersih

\section{HASIL DAN PEMBAHASAN}

Pada penelitian ini terdapat enam buah lintasan yang menjadi lokasi pengamatan.Penentuan lokasi ini ditujukan untuk mengetahui arah alir dari pencemaran lindi yang terjadi di wilayah sekitar Ciparay. Lintasan ini terletak pada jalur yang menghubungkan antara pusat pembuangan sampah menuju pemukiman warga.

Gambar 3 lintasan A terletak tepat di atas tumpukan sampah sepanjang $110 \mathrm{~m}$, dengan ketinggian sekitar 866-879 m, memiliki nilai resistivitas terkecil degan rentang 0,0283-0,429 $\Omega \mathrm{m}$ yang diindikasikan sebagai wilayah yang mengalami pencemaran.

Lintasan B sepanjang 75 m merupakan lintasan yang terletak sebelah selatan lintasan A menjauhi wilayah pemukiman penduduk yang terletak pada ketinggian $874-879 \mathrm{~m}$, memiliki resistivitas rendah yakin sekitar 0,209-0,673 $\Omega \mathrm{m}$ dan di indikasikan sebagai tumpukan sampah yang telah ditimbun.

Lintasan C terletak di wilayah barat dari lintasan A sepanjang $100 \mathrm{~m}$ yang terletak pada ketinggian 874 - $884 \mathrm{~m}$, nilai resistivitas berkisar 0,0244-0,812 $\Omega \mathrm{m}$. Nilai tersebut dapat menunjukan keadaan tanah yang tercemar.

Lintasan D merupakan lintasan yang terletak di wilayah pemukiman penduduk yang terletak pada ketinggian 838 - $843 \mathrm{~m}$, sepanjang $60 \mathrm{~m}$ untuk melihat kondisi pencemaran pada penampang lapisan tanah tersebut. Pada lintasan ini nilai resistiviatas terkecilnya pada rentang 5,27-9,87 $\Omega \mathrm{m}$ memberikan gambaran bahwa wilayah ini sudah mengalami pencemaran namun tidak terlalu besar nilainya.

Lintasan E sepanjang $45 \mathrm{~m}$ yang terletak pada ketinggian 853-860 m merupakan lintasan terpendek pada pengamatan ini, nilai resistivitas terkecil terdapat pada rentang 2,19-4,83 $\Omega \mathrm{m}$ menandakan adanya peningkatan nilai resistivitas yang menandakan adanya penurunan tingkat pencemaran di wilayah tersebut.

Lintasan F terletak di wilayah timur dari titik aktif dari TPA Ciparay.Lintasan sepanjang $100 \mathrm{~m}$ ini terletak pada ketinggian 874 - $880 \mathrm{~m}$ dan berada tepat di atas tumpukan sampah. Pada lintasan ini nilai resitivitas terkecil pada rentang 6,94-14,8 $\Omega \mathrm{m}$, dan menyebar di sepanjang lintasan. Jika dilihat bedasarkan nilai resistivitas wilayah ini merupakan wilayah yang tercemar.

Penelitian di TPA Ciparay disertai dengan data uji kualitas air. Uji kualitas air yang dilakukan meliputi kualitas fisik dan geokimia. Uji kualitas air ini yang dapat membantu untuk memperkuat analisa mengenai pencemaran yang terjadi.

Kualitas Fisik meliputi Suhu, TDS, konduktifitas dan COD, sedangkan untuk geokimia meliputi derajat keasaman, kandungan Nitrat, Nitrit, Amonia dan kandungan Fe.

Suhu air pada sampeldi sumur warga dan kolam berada pada rentang suhu kamar, sedangkan untuk sampelair di wilayah sampah dan jalur menuju pemukiman memiliki nilai yang lebih tinggi pada kisaran $30-40^{\circ} \mathrm{C}$. Suhu tinggi tersebut dapat di akibatkan oleh adanya kontaminasi dari lindi yang meningkatkan jumlah organisme di dalam air.

Pada uji kadar COD nilai maksimal yang diperbolehkan untuk baku mutu air bersih adalah 10 $\mathrm{mg} / \mathrm{L}$. Berdasarkan hasil pengujian pada kedelapan sampel air diperoleh hasil tiga buah sampel memiliki kandungan COD dibawah harga maksimum yang diperbolehkan. Ketiga sampel tersebut adalah sampel yang berasal dari sumur warga dan kolam ikan. Sedangkan untuk sampel yang berada di wilayah dekat dengan TPA dan wilayah sekitar pemukiman, diperoleh nilai yang sangat tinggi.

Pada parmeter TDS ini jumlah maksimum yang diperbolehkan adalah 1500 ppm.Berdasarkan hasil uji diperoleh enam sampel melampaui batas tersebut, sampeltersebut merupakan sampel lindi yang terdapat pada sampah.

Untuk nilai konduktifitas, pada standar baku mutu air bersih nilai maksimal yang diperbolehkan $1250 \mu \mathrm{S} / \mathrm{cm}$ dan dari 12 air sampel yang di uji diperoleh 8 sampel memiliki nilai yang jauh diatasnya. Sampel-sampel tersebut merupakan sampel air di wilayah dekat sampah. Sedangkan untuk sampel sumur warga dan kolam nilainya 


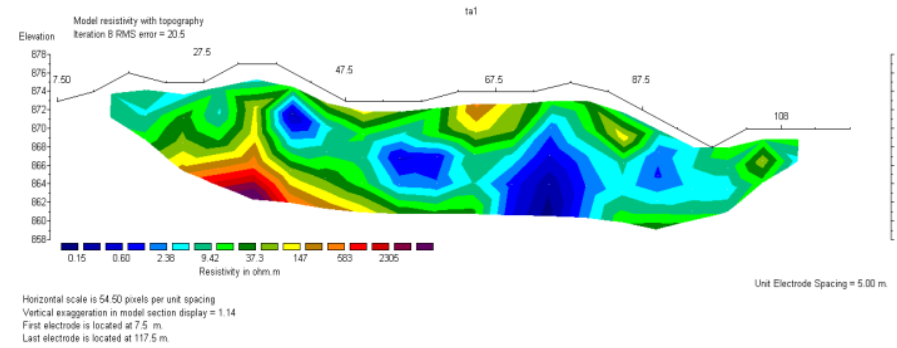

(a)

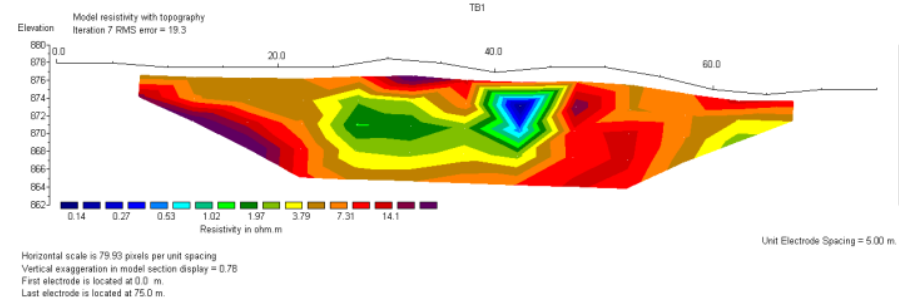

(b)

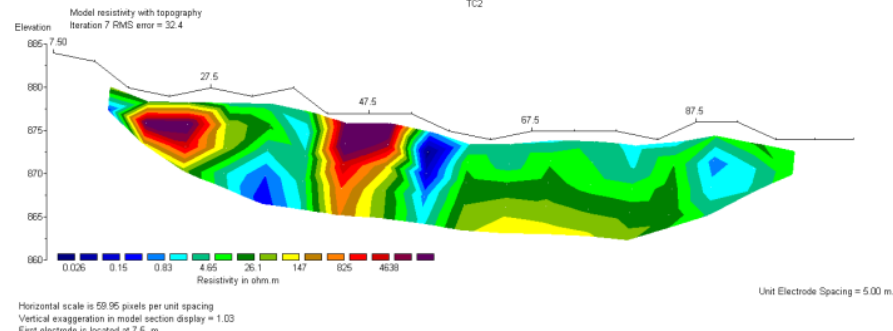

(c)

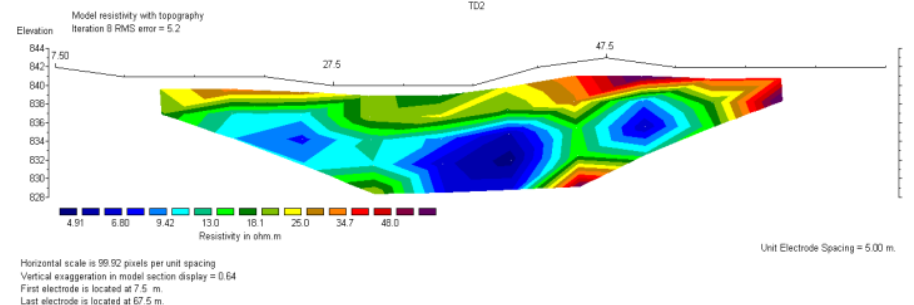

(d)

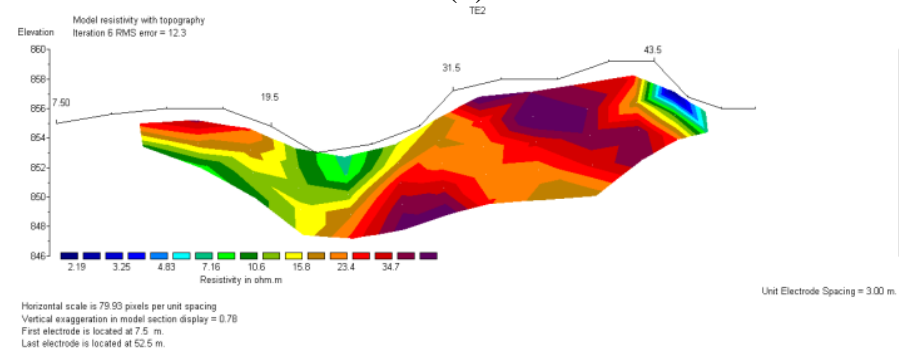

(e)

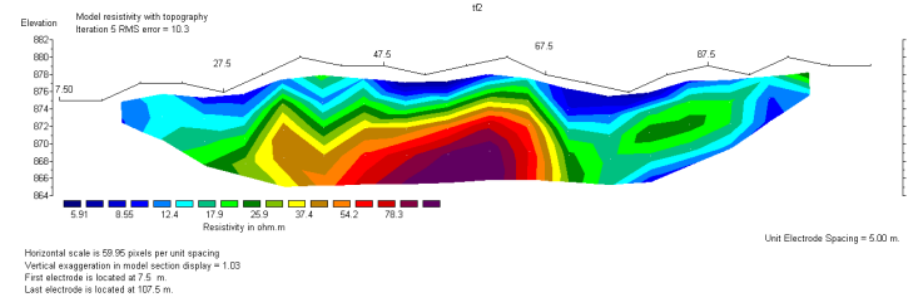

(f)

Gambar 3 Hasil pencitraan resistivitas lapisan tercemar : (a) Lintasan A:kedalaman 3,75 m nilai resistivitasnya 0,028-6,51 $\Omega \mathrm{m}$, (b) Lintasan B: kedalaman 3,75 m nilai resistivitasnya 0,019-1,12 $\Omega \mathrm{m}$, (c) Lintasan C: kedalaman 1,25 m nilai

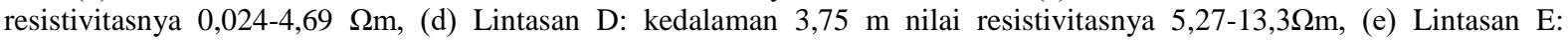
kedalaman 2,25 m nilai resistivitasnya 2,19-7,16 $\Omega \mathrm{m}$, (f) Lintasan 6: kedalaman 1,25 m nilai resistivitasnya 4,82-15,3 $\Omega \mathrm{m}$. 
berada di bawah harga maksimum yang diperbolehkan.

Untuk derajat keasaman $(\mathrm{pH})$ secara keseluruhan berada pada rentang yang masih termasuk mutu baku air bersih yakni kisaran 6,5-9,0. Akan tetapi terdapat dua buah sampel yang memiliki nilai di bawah 6,5. Sampel tersebut merupakan sampel yang paling dekat dengan TPA.

Untuk uji amoniak total hanya dilakukan pada delapan sampel air. Dari delapan sampel air terdapat 5 sampel yang memiliki kadar cukup tinggi pada kisaran 153-183 mg/L. Nilai tersebut diperoleh pada sampel di wilayah sekitar TPA sedangkan untuk hasil uji di sumur warga dan kolamnya nilainya hanya berkisar 1-10 mg/L. Nilai tersebut melebihi nilai maksimum baku mutu air bersih.

Pada uji kadar nitrat nilai maksimal yang diperbolehkan untuk baku mutu air bersih adalah 10 $\mathrm{mg} / \mathrm{L}$. Kadar nitrat yang terkandung secara keseluruhan masih berada di bawah batas maksimum yang diperbolehkan, yakni 0,04-1,21 mg/L.

Pada uji kadar nitrit nilai yang diperbolehkan sebagai kategori air bersih adalah $1 \mathrm{mg} / \mathrm{L}$. Adapun hasil pengujian dari kedelapan sampel air diperoleh nilai dengan rentang 0,002-0,13 $\mathrm{mg} / \mathrm{L}$, masih dibawah jumlah maksimum yang diperbolehkan.

Pengujian kadar $\mathrm{Fe}$ pada air memiliki nilai maksimum yang diperbolehkan baku mutu air bersih yakni $1 \mathrm{mg} / \mathrm{L}$

Berdasarkan hasil pengujian pada kedelapan sampel air diperoleh hasil tiga buah sampel memiliki kandungan Fe yang sangat tinggi berkisar 3-19 mg/L. Ketiga sampeltersebut adalah sampel yang berada di wilayah dekat dengan TPA. Sedangkan untuk sampel yang berasal dari sumur warga, kolam ikan dan wilayah sekitar pemukiman, diperoleh rentang 0.001$0.67 \mathrm{mg} / \mathrm{L}$.

\section{KESIMPULAN}

Berdasarkan nilai resisistivitas yang tercemar pada data setiap lintasan maka dapat disimpulkan dari data geolistrik bahwa lintasan A,B,C dan F yang berada di tempat sampah diduga terdapat pencemaran air di daerah tersebut tercemar. Sedangkan pada lintasan D dan E yang berada disekitar pemukiman penduduk memiliki nilai resistivitas ada yang mendekati rentang nilai fresh water sehingga dapat dikatakan belum terjadi pencemaran yang berat, tetapi berpotensi untuk tercemar.

Berdasarkan nilai uji kualitas air yang dilakukan pada delapan titik sample, terdapat 5 buah sampelyang tercemar yakni sampelpada jalur dari TPA menuju ke pemukiman penduduk. Sedangkan untuk sampel air sumur penduduk masih dikategorikan sebagai air bersih.

Berdasarkan nilai resistivitas tanah dan air pada titik sampel diperkirakan pencemaran mengarah ke daratan rendah menuju arah utara.

\section{DAFTAR PUSTAKA}

Darsono. (2008). Tapak Pembuangan TPA, Diktat Kuliah Fisika UNS, Universitas Negeri Sebelas Maret, Surakarta.

Loke, M.H. (2000). Electrical imaging surveys for environmental and engineering studies. A Practical Guide to 2D and 3D Surveys.

Marganingrum, D., Suparyanto, I.H., Karningsih, N., Widarto, D.S., Somantri, I. (2006). Studi Dampak TPA Terhadap Air Tanah. Studi kasus: TPA Babakan Ciparay, Kabupaten Bandung (Sub kegiatan: 4977.0270), Pusat Penelitian Geoteknologi LIPI, Bandung.

Notodarmojo, S. (2005). Pencemaran Tanah dan Air Tanah, Penerbit ITB, Bandung. 